\title{
Emirati Youth's Attitudes Towards Citizenship Values (Applied Study on A Sample of Students of The Emirates College of Technology and Al Ain University of Science and Technology) April 2020
}

\author{
Dr. Taher Awad Basha \\ * Assistant professor Emirates College of Technology \\ Email: eltahir.basha@ect.ac.ae \\ Received: 25 June. $2020 \quad$ Revised: 31 August. $2020 \quad$ Accepted: 15 Nov. 2020 Published: 01 Jan 2021
}

\begin{abstract}
:
This research aims to identify the attitudes of Emirati youth towards citizenship and their level of awareness of it and to determine the extent of their commitment to those values by Identifying their contribution to promoting the values of citizenship and strengthening the values of belonging, loyalty, and positive participation What is the relationship between young people's awareness of the concept of citizenship and translating this reality into practical images. Then stand on the level of commitment to the values of citizenship among Emirati youth and how they can contribute to strengthening the values of rights, duties, and social responsibility. The study also aimed to identify the threats to the values of citizenship from the point of view of young people in light of the increasing media openness, socially, culturally, security, and economically. It emerged through the results that the vast majority of respondents are fully aware of the concept of citizenship and feel proud that they are citizens of the United Arab Emirates. Furthermore, it was found through the results of the study that there are no negative effects of the presence of expatriate workers and the multiplicity of nationalities within the country working to weaken the concept of citizenship among the sample members.

The recommendations of the study included the following:

1 / The need to give the concept of citizenship the utmost importance in the media and educational curricula.

2 / The need to support and strengthen the concept of citizenship among young people by launching community initiatives led by young people themselves.

3 / Immunizing youth against the negative effects of media openness and new media by focusing on developing citizenship values.

4 / Paying attention to historical, religious, and cultural symbols and promoting them through the means of tourism to enhance the concept of citizenship for the people of the same country with the importance of motivating young people to loyalty to the homeland, pride in its heritage and adhere to its customs.
\end{abstract}

Keywords: Attitudes- Citizenship Values-Attachment to the Nation - Belonging. 


\section{Introduction:}

The concept of citizenship is an old concept of human civilizations. It has continued to evolve and renew, and citizenship is justice. Equal rights and duties among all citizens, where the term establishes a strong relationship between the homeland and the citizen, and several levels of the individual's sense of citizenship.

1.The feeling of the individual what connects him and the rest of the group, such as the homeland, neighborhood, blood, and lifestyle, including values, customs, traditions, systems, beliefs, professions, and laws.

2.The individual's sense of attachment to the homeland and belonging to the group.

3 . Feeling the continuity of this group over the ages and ages, and citizenship receives attention on several tracks, from a legislative point of view that all the countries of the world technically guarantee the rights and duties of the citizen, but from an educational point of view, states work to devote the awareness of the citizen values and practices of the young people to achieve national integration, and politically works to involve the sons of the state in contributing to the building of their state.

\section{Recent developments in today's world have made the issue of citizenship and identity a priority of global attention for a number of reasons, including:}

1. The emergence of regional blocs, such as the European Union.

2. Multiculturalism in many countries of the world as a result of voluntary or voluntary migrations and the transfer of labor that has been calling for its cultural right while in immigration.

3. Eastern Europe was freed from the dominance of the Russians, which resulted in ethnic and national conflicts.

4.The emergence of what was known as political Islam, which changed many of the juristic concepts.

5.The emergence of globalization changed the traditional view of some concepts such as the state, the country, and citizenship.

6.The appearance and mixture of several currents of thought hidden behind some slogans in an attempt to penetrate the minds of youth in our Arab and Islamic world.

We will look at the definitions of citizenship and patriotism through the following pages.

\section{Literature Review:}

(1) A study (Al-Sabeeh, 2005) on citizenship as envisioned by high school students in the Kingdom of Saudi Arabia, as the number of the sample population reached (104) students whose ages ranged between (16-19) years, using measures of citizen rights and duties, the study reached that $80 \%$ of students are aware of the rights and duties of citizenship and that $89.8 \%$ showed a high level of satisfaction with the performance of their duties. The study recommended the need to take care of the concept of citizenship and study the factors that contributed to the weak awareness of students with it. (Al-Sabeeh, 2005)

(2) Study (Al-Amer, 2005). It aimed to know the effect of cultural upheaval on the concept of citizenship among Saudi youth, which was conducted on (544) university students using a questionnaire consisting of (156) paragraphs, which clarified that there are differences of statistical significance between males and females are after belonging to the homeland. The differences favored the females and the absence of differences in the other dimensions of 
citizenship. (Al-Amer, 2005).

(3) The study (Ibn Arab, 2009). which was about that what students know about citizenship? (222) Algerian students answered that citizenship means rights and duties. $15,81 \%$ defending the country said $13.5 \%$ said it means loving the country, $11.58 \%$ belonging to the homeland, $11.33 \%$ development, and 6,22\% they said that they are subject to the laws $4.11 \%$ Pride and glory $3.36 \%$ Pride in the country $3.11 \%$ Improving living $0.37 \%$ Participation in joint fateful decision-making $0.74 \%$ of these results reflect that the issue of citizenship is still far from awareness and awareness of students. (Ibn Arab, 2009)

(4) Study (Al-Azzawi) the concept of citizenship among Iraqi youth, in which the descriptive research adopted the descriptive-analytical method. He concluded that the concept of citizenship is still not sufficiently understood by a most Iraqi youth. There is differentiation in realizing some of its dimensions and the absence of others, especially the dimensions of pluralism, freedom, and political participation. The researcher responds that this may be due to the fact that the Iraqi youth received an unexpected shock that almost destroyed its existence as a result of the American occupation of Iraq, but the psychological and cultural formation of the Iraqi individual through the ages gave birth to a sense of belonging as a people and a nation with an ancient homeland that has a historical depth extending through the ages and that the occupation is opposed. (Sami Mahdi Al-Azzawi)

(5) Study of Hanan Murad, the study showed a contradiction in the structure of awareness and mental image among young people about some of the vocabulary associated with pluralism, openness to the other, freedom, and political participation. And social. The study also indicated a state of intellectual and ideological conflict between the intellectual and ideological currents present in the Algerian arena, whether with a religious dimension that calls for the preservation of privacy and self-identity or currents with incoming western approaches calling for liberation. Finally, the study showed the exposure of a clear deficiency in the role of many institutions of society Cultural and educational formation and support. It developed an awareness of the image required by society's goals, absorbing the events and ideas emitted on the ground, seeking to confirm the continuity of preserving the roots and developing a sense of identity and belonging among the Algerian youth.

As for the statistically significant differences attributable to gender, type of education, place of residence, level of family income, educational status of the father, and sources of political culture, the statistically significant differences came in some dimensions of citizenship in favor of university education and residence in cities. (El-Sayed, 2010)

(6) Study (Al-Nabhani, 2007), which aimed to know the most important contemporary challenges facing the development of citizenship in Omani society, using a questionnaire consisting of 24 paragraphs distributed on four main axes representing the challenges facing citizenship, namely (educational, political, economic And social), which was applied to a sample of (194) male and female students from social studies students that showed that the political challenges ranked first, followed by economic challenges, educational challenges, and finally social challenges. (Al-Nabhani, 2007)

(7) Al-Qahtani's study (2010) sought to identify the level of citizenship values among university students in the Kingdom of Saudi Arabia, and the contribution of these values to achieving preventive security, and to detect obstacles that reduce their exercise of these values, and to identify the obstacles to activating the exercise of values Citizenship among young people in the universities of the Kingdom, the study used the descriptive approach, and the questionnaire was applied to a sample of Saudi university students, and the study resulted in a set of results, the most prominent of which are the values of citizenship subject 
of study - participation and order at a high level to very high in the cognitive and emotional side, while I got Low to medium level in the behavioral aspect, and the results revealed the obstacles that lead to the failure to exercise the values of citizenship in the required manner, which include the weakness of the suitability of the university educational climate for young people to practice the values of citizenship on the ground. (Al-Qahtani, 2010)

(8)The study of Al said, and Ismail (2010) sought to identify the university's role in educating students about the principles of citizenship in light of the effects of contemporary global challenges and to stand on the level of university students' awareness of the principles of citizenship. The study used the descriptive approach, and the study tool was a questionnaire. It was applied to a sample of students. The results of the study concluded that the university does not contribute effectively to educating students about the principles of citizenship, which requires reviewing the educational process in universities in all its aspects, defining the roles and goals of all university employees, and activating academic and other activities at the university in order to enhance the principles Citizenship.

(Shamani \& Saad, 2012)

(9) Aumarah study (2010) identified some values of citizenship necessary to face cultural identity challenges, which the university professor must develop among students to meet these challenges. The study used the descriptive approach using the questionnaire tool applied to a sample of 700 students. The study found deficiencies The university professor plays a role in developing the values of citizenship from the point of view of the study sample, especially the values of belonging, loyalty, tolerance, respect for the other, the values of political awareness, and the values of volunteer teamwork. (Amara, 2010)

(10) Al-Azmi and Al-Rumaidhi study (2011) aimed to identify teachers' role in developing national values among high school students in the State of Kuwait. To achieve this goal, the questionnaire tool that included a set of national values was prepared and applied to a random sample of male and female teachers. In secondary schools, the study reached several results, the most important of which are: that the sample members 'estimates of the teachers' role in developing national values came largely in all fields, and there were statistically significant differences attributable to the gender variable, years of experience, and the educational region. (Al-Azmi, 2011)

(11) The study of Al-Shamani and Saad (2012) aimed to identify the level of good university students 'attitudes towards the elements of identity and affiliation, and to identify the role of curricula and student activities in supporting identity and belonging, the study used the descriptive approach, and applied the study tool to a random sample made up Out of 100 students from university students in various specializations, the results of the study reached a decrease in the students 'awareness of the study sample of the elements of the national identity and its components, and the presence of relative awareness among students of the risks surrounding the individual affiliation circles. (Shamani \& Saad, 2012). (12) (Woyach, 1992) study which examined the interest of social studies in citizenship and improving citizenship culture in the United States of America that more than half a million high school students participate in programs specifically designed to encourage the culture of citizenship leadership and develop their skills, which recommended the need for public education schools to play their part in developing leadership and citizenship. (Woyach, 1992)

(13) The Lung 2004 study focused on determining the ability of the Hong Kong primary school to develop civic education for its pupils and identifying teachers' opinions to determine the best topics that achieve civic education. The results of the study revealed the 
existence of some obstacles that face the implementation of education. Civilization, including the weakness of teacher preparation in the field of civic education, and the results identified some topics of civil education that the curriculum should cover. (Lung, 2004)

(14) The study of Sim (2005) sought to know the different dimensions of citizenship education through the Social Studies course in secondary schools in Singapore. The study results concluded that the teacher's role is to emphasize the development of thinking among students and become enlightened citizens with the ability to assume responsibility, cooperation, participation, Affiliation, shared culture, and other values of citizenship. (Sim, 2005)

(15) The Warwick 2007 study sought to identify the level of commitment of primary schools in England to achieve the National Initiative for Citizenship Education by identifying practices used in implementing curricula, in practicing student activities, and in all services provided to support the implementation of the initiative and resulted in the results of the study on pupils' possession of citizenship values, especially the values of love to help others, belonging to the local environment, and the larger community in which they live. School on the implementation mechanisms of the national initiative to raise citizenship in primary schools. (Warwick, 2007).

\section{Comment on Previous Studies:}

The results of previous studies show that:

1. The scarcity of Arab studies on the concept of citizenship in general.

2. There is no study (to the researcher's knowledge) about citizenship for young Emiratis.

3. Most Arab and foreign studies have concerned young people, especially university and school students, which this study met.

Reviewing previous studies' results helped the researcher formulate the problem of the current study as the researcher benefited from these studies in identifying the appropriate curriculum for the study and the tools that serve the objectives of the study and the appropriate sample and how to choose the study community.

\section{The problem of study and the need for it:}

Citizenship and identity are two basic concepts that the modern state stands on, as they are the constitutional basis for equal rights and duties among members of the same state, as they are important tools for building a good citizen who can live in peace and tolerance with others on the basis of equality and equality of opportunity as they constitute a common heritage of values, principles, customs and behaviors that It contributes to forming the citizen's personality and gives it characteristics that distinguish it from others. The concept of citizenship has multiple dimensions that are integrated and coherent. First, it is represented in the economic dimension. One of its functions is to satisfy the individual's material needs that preserve his dignity, then the legal dimension, which includes his duties regulating the relationship between the ruler and the ruled. Then the cultural dimension, which is concerned with the psychological and spiritual aspects of individuals and groups on the basis of respect for cultural identity and rejects attempts at isolation.

\section{We can summarize the importance of research in the following:}

1.The scarcity of research and studies on the subject of citizenship in the UAE, according to the researcher's knowledge. 
2. This study acquires its importance through its approach to the concept of citizenship among young people in light of contemporary and potential future conditions.

3. The issue of citizenship has become a national concern that occupies Emiratis, as everyone hopes to arrive at a precise concept of citizenship

4. The transformations that the world is witnessing today, technological development, and open media space, all this in one way or another, affected the concept of citizenship in our Arab and Islamic world.

5. A modest attempt to measure the concept of citizenship among Emirati youth in light of the demographic composition of the expatriate labor in the country from most of the world as a result of the accelerating development of the country.

6. The researcher considers this study to be part of the return of the beautiful to this country, which we coalesced with his family by virtue of the length of time that we lived among them.

\section{Research Aims:}

1.This research aims to identify the attitudes and awareness of Emirati youth towards citizenship.

2. Identifying the extent of the commitment of Emirati youth to the values of citizenship through:

A. Do Emirati youth contribute to enhancing the values of citizenship and supporting the values of belonging, loyalty, and positive participation?

B. Is there a relationship between youth awareness of the concept of citizenship and translating this reality into practical images?

\section{Research Problem:}

The research problem is summarized in answering the following questions:

To what extent are Emirati youth aware of the concept of citizenship?

1.What is the level of commitment to the values of citizenship among Emirati youth?

2.What is the extent of the contribution of the youth in promoting the values of rights, duties, and social responsibility?

3. What are the threats to citizenship values from the respondents' point of view in light of the increasing media openness socially, culturally, security, and economically?

4.What is the impact of expats on Emirati citizenship values?

\section{Concepts and Terms:}

\section{Direction:}

Definition of "1"ALLPORT: a trend is one of the states of mental preparation and nervousness regulated by experience. It has a directive on individuals 'responses to different things and situations. (AIIPORT, 1954)

BOGARDUS 's definition of the tendency to act, whether positive or negative, towards a situation in an environment that identifies positive or negative values for such behavior. While the definition of Newkemp is a state of willingness to provoke motivation because one's attitude towards a particular topic is a willingness to provoke one's motives in relation to the subject, and this readiness is influenced by one's experience and previous knowledge of the subject negatively or positively. (Bougardous, 1931)

Harry Apshow UPSHOW'3 'defines trends as (the attitudes of individuals in facing the 
issues, issues, and matters surrounding them).

Youth:

The definition of the concept of youth raises a great controversy among researchers in the social sciences, so the researcher will introduce the most important definitions that the researcher has reached by looking at some of the literature.

\section{The concept of youth in the lexicon:}

Young people towards modernity, for a young male, are gathered by young men and women, and young women and young men gather young women.

\section{In sociology:}

Sociologists define the youth category based on society as a frame of reference, and they define it according to age by a succession of social roles. There are two types of roles: the age of preparation and the age of effectiveness and completion, the student's role is to form and acquire knowledge while the employee has completed his previous role. (Al-Zubaidi, 2006)

Sociologists believe that the youth period begins with the individual entering the society after qualification and integration to perform his role and then ends after he represents a social position in which he can play his role beneficially within the social system. And young Hijazi defines youth: as the critical mass that holds the most important opportunities for the development of society and making its future. (Hijazi, 2006)

Through the foregoing, the researcher proposes a procedural definition as follows:

Young people are an active group with goals and aspirations ranging in age from fifteen to twenty-five years in which the young man or young woman has biologically completed sexual development, and at the legal level, which determines the age of majority at the age of eighteen and socially the individual can play a social role that qualifies him to reach the social status that he wants it inside society.

\section{The concept of values:}

Linguistic concept: (Values, 2018)

The 'value' is one of the values that is done, and past is valuable, and its origin is valuable, meaning straighten it because it takes the place of the thing, so the value is the number of items in the calendar. And the money is valuable if it does not last for anything.

\section{Idiomatic Concept:}

The idiomatic meaning of value does not deviate from the linguistic meaning. It means idiomatic: (What we do as a standard) and from the synonyms of value (price and proverb). (Library, 2014)

Based on the above, it can be concluded that value is the sum of all opinions and beliefs through which the individual looks at any psychological subject: human being, event, behavior, or something that directs his desires and attitudes towards these subjects and determines the nature of his behavior towards them: acceptance, rejection, indifference, and sympathy. (Al-Gohary, 1996)

The dictionary of meanings (Al-Kafi, 2005) in the definition of the concept of values: the combination of values and values, the value of the material, value of the object and the value of the culture, the price of the price.

Values: The religious, moral, and social virtues that undergo the life of human society. The concept of values is a multi-meaning concept, and the reference to this is the multiplicity of areas in which this concept is used

As stated in the philosophical dictionary $(1682)(\mathrm{R}, 1968)$ by his view of values as a measure of good, evil, right, and right, and defined the value as a term that is called all that 
is worthy of one's attention and care, for psychological, economic, moral and aesthetic considerations.

Al-Jawhari and others definition of (1996) that value is human preferences, perceptions of what is desirable at a more general level, so values include all the themes, circumstances, and principles that became meaningful during the long human experience, the frame of reference for individual behavior. p. (Ibn Manzur R, 1968)

It is also defined as the 'ideals that prevail among individuals and permeate them, passed down by generations and defended as much as possible. (Ghaith, 1995)

The researcher concludes from these definitions that the values are all qualities of psychological, moral, and social importance that guide the mind and behavior; the values in this concept are criteria that determine what is desirable and what is undesirable and good and bad things, as they are considered calendar provisions for all of the above.

\section{The Concept of Citizenship:}

Citizenship in the language belongs to citizenship to the homeland, which is the home in which the human being and the people reside in the homelands. It is said that his homeland is in place and that he is aware of any residence in it and his homeland has taken him home, and the land of any place in which he has taken it is a place where he resides. (Al-Kabbaj, 2006)

\section{Citizenship in the Islamic Concept:}

It expresses the nature and essence of the links between Dar al-Islam (the homeland of Islam) and those based on it, Muslims, and others. (Jaafar Sheikh Idris, 2005)

\section{The definitions of Citizenship Stated:}

Citizenship in the language: derived from a homeland, which according to the Book of the Arab Tongue of the Son of Perspective 'The homeland is the home in which you live, and it is the home of a man and his place and a homeland of the place and the homeland of the place, and the homeland. And the citizen who grew up in a country or lived in it and the earth: its homeland and its settlement, i.e., taken by a homeland.

\section{Ibn Montour.: Tongue of the Arabs, 1968, p. 451}

In the terminology: Patriotism comes in the sense of patriotism in the sense of patriotism in the sense of patriotism in a clear reference to feelings of love and association with the homeland and the resulting emotional responses, citizenship is the characteristic of the citizen, which determines the citizen's rights and national duties and the individual knows his rights and performs his duties through national education, and citizenship is characterized by a special kind of loyalty of the citizen to his country and his service in times of peace and war and cooperation with other citizens through official and voluntary institutional and individual work in achieving the goals that everyone is entitled to and unite for. Plans are drawn, and budgets are drawn. Ahmed Hekmat Shamseddine defined it as: "In its broad sense, the legal link between the individual and the state in which he resides consistently, this relationship usually defines the rights and duties of the individual in the state, i.e., the individual citizen, the full member of the state, and citizenship as the fundamental legal status in the current state."

The terminology, too, is a status or social relationship between a natural individual and a political community (state). Through this relationship, the first party offers loyalty, and the other party takes charge of protection, and this relationship between the individual and the state is united through the law. A political description of the community members under its homeland (Al Kabaj, 2006), as it is a situation that makes the relationship with the state a partnership relationship in the homeland. (Al-Kabbaj, 2006) citizen. 


\section{Manifestations of Citizenship (Idris)}

1. Optional and spontaneous participation in the form of various social activities.

2 . Protection of public property and private property.

3. Respecting the laws.

4. Respecting the rights and freedoms of others.

5. Sincerity in serving the country and defending its gains.

6. The initiative to participate in joint duties.

7. Adherence to national values.

(Idris 2005) considers citizenship a geographical affiliation to a specific land, while identity is a cultural affiliation to certain values, beliefs, and standards. (Idris, 2005)

The components of citizenship (Al-Habib, 2015)

1. Belonging to the homeland: It is the internal feeling of the individual who makes him work with sincerity to raise the profile of his homeland, protect it and be proud of it.

2. Rights: The concept of citizenship includes rights that all citizens enjoy and are at the same time duties of the state and society, such as preserving private rights, providing health care, providing education, preserving religion, providing basic services, and personal freedom.

3. Duties: including respecting the system, defending the country, and preserving public facilities.

4. Community participation: One of the most prominent features is that the citizen participates in community work.

\section{What factors helped the spread of citizenship rights?}

Among the factors that helped spread the rights of citizenship are the following:

1. People move from the countryside to the city, where residency requires the provision of some individual rights and rights and obligations for the state.

2. Economic prosperity and the subsequent openness to the global market and the development of workers 'wages have an indirect effect on the emergence and spread of the concept of citizenship and the declaration of the accompanying rights such as social security and workers' rights.

3. The development of the means and media that play an important role in developing and developing the concept of citizenship by increasing contact between citizens.

4. The interest of official and unofficial international organizations in citizenship and human rights issues, that concern that led to the rapid spread of citizenship and interest in it. (Ibn Arab, 2009).

\section{Study Approach:}

For this study to achieve its goal and to achieve systematic integration, and to answer the study's questions and the nature of the study and its affiliation with descriptive studies, this study uses the descriptive method in the survey method, which means describing the phenomenon and identifying it and justifying the conditions and practices or evaluation and comparison as it aims to access data that can be classified, interpreted and generalized. In order to benefit from it in the future (using the survey of methods of practice for a sample of the youth category, using the questionnaire sheet as a tool to collect data for the study sample).

Study Community: The meaning of the study population refers to the total group of elements that the researcher seeks to generalize the results related to the studied problem. In this study, the Emirati youth research community is represented by applying to a sample of 
200 students from both Emirates College of Technology and Al Ain University of Science and Technology.

The study sample: It is a part of the research community that is adequately represented. It is a partial group of social units with the same characteristics as the original community. The researcher used a random sample for students of both universities to accommodate the sample members.

Study Tool: The researcher relied on the questionnaire as a tool for collecting information because it is one of the methods that are used to collect primary, basic or direct data from the study sample by directing a set of specific and prepared questions in advance to identify specific facts from the respondents, and the researcher's choice of the questionnaire form imposed by nature The study, and the closed questionnaire was chosen that requires the sample members to select the appropriate answers and give their point of view from the given responses, by applying this to (the study sample). The researcher has followed a set of methodological steps to reach the questionnaire to the proper framework by defining the research community and the type of information that is intended to obtain it and presenting the questionnaire to a group of experts and specialists as arbitrators. Based on the proposed amendments and based on the expert's observations, some questions were reformulated, and after the completion of the form's finalization, it was distributed to the study sample.

\section{Procedural Definition of Citizenship:}

The researcher defines citizenship (procedural) as the close connection between Emirati youth and his homeland based on the foundations of belief, ethics, principles, and values, the comfort of rights, and commitment to duties as he works on sincerity in serving the country and defending his voluntary and spontaneous participation in the form of various social activities that result in that feeling of pride and honor of belonging In the light of a reciprocal relationship, the fruit of which is peace and prosperity of the homeland and the

\section{Committee of Experts and Specialists:}

1 / Prof. Dr. Hassan Terrab, College of Education, United Arab Emirates University.

2 / Dr. Hassan Mustafa, Associate Professor of Media, Ras Al Khaimah University.

From the Emirates College of Technology:

3 / Dr. Muhammad Ahmad Fayyad, Associate Professor, Dean of Media.

4 / Dr. Abdul-Malik Al-Danani, Associate Professor of Media.

5 / Dr. Al-Sadiq Rabeh, Associate Professor of Media.

6 / Dr. Ghada Saleh, Associate Professor of Media.

7 / Dr. Khaled Darar, Assistant Professor of Information.

8 / Dr. Amjad Abdul Qadir, Assistant Professor of Information.

\section{Tool Credibility:}

Credibility is one of the most important conditions that must be met in building standards and tests. The apparent honesty represents the general appearance of the tool in terms of the type of vocabulary, how it is formulated, how clear it is, and instructions of the tool, and the degree of clarity and objectivity. The priority is on a committee of experts and specialists. Some amendments were made to it, including merging some paragraphs, deleting and reformulating others in light of their opinions and suggestions. Thus the tool became in its final form consisting of thirty-one paragraphs.

\section{Tool Experience:}

The tool was applied to a random sample of (20) male and female students randomly chosen from Emirates College of Technology and Al Ain University of Science and 
Technology, which showed through the application clarity of instructions and paragraphs and that the time taken to answer was between (15-20) minutes.

Tool stability:

It was extracted by retesting method two weeks after the first application to obtain a correlation coefficient of (0.84) and by an internal consistency method to obtain a coefficient of cohesion of $(0.81)$

Data analysis and interpretation:

Table No. (1) shows the distribution of sample individuals according to the variable 'type.'

Table No. (1)

\begin{tabular}{|c|c|c|c|}
\hline TOTAL & FEMALE & MALE & GENDER \\
\hline 200 & 80 & 120 & Numbers \\
\hline $100 \%$ & $40 \%$ & $60 \%$ & Percentage \\
\hline
\end{tabular}

From the results of the field study, it is clear that $60 \%$ of the males, while the percentage of females reached $40 \%$ of the sample. It is noticeable that the number of males is close to the number of females in the study sample.

Table No. (2) shows the distribution of the sample population according to the age group.

Table No. (2)

A table showing the distribution of the sample population according to age

\begin{tabular}{|c|c|c|c|c|c|}
\hline TOTAL & More than 35 & $\begin{array}{c}\text { From 30 to } \\
\text { less than 35 }\end{array}$ & $\begin{array}{c}\text { From 25 to } \\
\text { less than 30 }\end{array}$ & $\begin{array}{c}\text { From 20 to } \\
\text { less than 25 }\end{array}$ & Age \\
\hline 200 & 35 & 105 & 34 & 26 & Numbers \\
\hline $100 \%$ & $17.5 \%$ & $52.5 \%$ & $17 \%$ & $13 \%$ & Percentage \\
\hline
\end{tabular}

By asking the respondents about their age groups, it became clear that $52.5 \%$ fall in the age range (30-35), which is the highest percentage in the sample, which represented more than half of the sample, and its rate came to $17.5 \%$ within the age group (more than 35), while the age group (25-30) by 17\%, while the age group of (20-25) got the lowest percentage, which is $13 \%$.

Table No. (3)

:Table No. (3) shows the distribution of sample individuals according to specialization

\begin{tabular}{|c|c|c|c|}
\hline Total & $\begin{array}{c}\text { Humanitarian } \\
\text { colleges }\end{array}$ & Scientific colleges & Major \\
\hline 200 & 148 & 52 & Numbers \\
\hline $100 \%$ & $74 \%$ & $26 \%$ & Percentage \\
\hline
\end{tabular}

The human colleges came to allocate the sample members as follows: Human colleges by $74 \%$, then the scientific colleges and their percentage came to $26 \%$, and this is due to the researcher's knowledge that the number of students in the scientific specialization in the two universities is offset by the increase in their numbers in the human colleges. 
Table No. (4)

Table No. (4) shows the distribution of the sample population according to marital status:

\begin{tabular}{|c|c|c|c|c|}
\hline Total & Divorced & Single & Married & Social status \\
\hline 200 & 12 & 126 & 62 & Numbers \\
\hline $100 \%$ & $6 \%$ & $63 \%$ & $31 \%$ & Percentage \\
\hline
\end{tabular}

According to the marital status, the percentages of the respondents were as follows: Single in the first rank with $63 \%$, followed by the married group and it was $31 \%$, while the absolute percentage was the lowest and it was only $6 \%$.

The first axis is the level of citizenship among young people in loyalty, community participation, and responsibility.

Table No. (5)

Table No. (5) shows the respondents' responses to a paragraph regarding the extent of awareness of the concept of citizenship.

\begin{tabular}{|c|c|c|c|c|c|c|}
\hline Total & $\begin{array}{c}\text { Strongly } \\
\text { disagree }\end{array}$ & $\begin{array}{c}\text { Not } \\
\text { agree }\end{array}$ & Neutral & Agree & $\begin{array}{c}\text { Strongly } \\
\text { agree }\end{array}$ & $\begin{array}{c}\text { Degree of } \\
\text { Approval }\end{array}$ \\
\hline 200 & 0 & 0 & 0 & 18 & 182 & Numbers \\
\hline $100 \%$ & $0 \%$ & $0 \%$ & $0 \%$ & $9 \%$ & $91 \%$ & Percentage \\
\hline
\end{tabular}

To ask about the extent of awareness among respondents about the concept of citizenship came with the consent of all members of the sample distributed between approval strongly and approval - the proportion of those who strongly agreed with $91 \%$. In comparison, those who responded with a conciliator were $9 \%$.

Table No. (6)

Table No. (6) shows the respondents' answers to a paragraph: I am proud to be an Emirati citizen.

\begin{tabular}{|c|c|c|c|c|c|c|}
\hline Total & $\begin{array}{c}\text { Strongly } \\
\text { disagree }\end{array}$ & Disagree & Neutral & Agree & $\begin{array}{c}\text { Strongly } \\
\text { agree }\end{array}$ & $\begin{array}{c}\text { Degree of } \\
\text { approval }\end{array}$ \\
\hline 200 & 0 & 0 & 0 & 0 & 200 & Numbers \\
\hline $100 \%$ & $0 \%$ & $0 \%$ & $0 \%$ & $0 \%$ & $100 \%$ & Percentage \\
\hline
\end{tabular}

All members of the sample $100 \%$ strongly agreed with a paragraph: I am proud to be an Emirati citizen.

Table No. (7)

Table No. (7) shows the respondents' responses to a paragraph: The UAE flag scene makes proud.

\begin{tabular}{|c|c|c|c|c|c|c|}
\hline Total & $\begin{array}{c}\text { Strongly } \\
\text { disagree }\end{array}$ & Disagree & Neutral & Agree & $\begin{array}{c}\text { Strongly } \\
\text { agree }\end{array}$ & $\begin{array}{c}\text { Degree of } \\
\text { approval }\end{array}$ \\
\hline 200 & 0 & 0 & 0 & 0 & 200 & Numbers \\
\hline $100 \%$ & $0 \%$ & $0 \%$ & $0 \%$ & $0 \%$ & $100 \%$ & Percentage \\
\hline
\end{tabular}

All members of the sample $100 \%$ agreed to a paragraph: The UAE flag scene makes me proud.

Table No. (8) shows the responses of the sample members to a paragraph: The national peace awakens the national sense and loyalty feelings as well. 
Table No. (8)

\begin{tabular}{|c|c|c|c|c|c|c|}
\hline Total & $\begin{array}{c}\text { Strongly } \\
\text { disagree }\end{array}$ & Disagree & Neutral & Agree & $\begin{array}{c}\text { Strongly } \\
\text { agree }\end{array}$ & $\begin{array}{c}\text { Degree of } \\
\text { approval }\end{array}$ \\
\hline 200 & 0 & 0 & 0 & 0 & 200 & Numbers \\
\hline $100 \%$ & 0 & $0 \%$ & $0 \%$ & $0 \%$ & $100 \%$ & Percentage \\
\hline
\end{tabular}

All members of the sample agreed $100 \%$ to a paragraph: "National peace awakens national sense and loyalty feelings."

Table No. (9) Employment Schedule

Table No. (9) shows the responses of the respondents to a paragraph: My country's history heritage and customs are a source of pride.

\begin{tabular}{|c|c|c|c|c|c|c|}
\hline Total & $\begin{array}{c}\text { Strongly } \\
\text { disagree }\end{array}$ & Disagree & Neutral & Agree & $\begin{array}{c}\text { Strongly } \\
\text { agree }\end{array}$ & $\begin{array}{c}\text { Degree of } \\
\text { approval }\end{array}$ \\
\hline 200 & 0 & 0 & 0 & 0 & 200 & Numbers \\
\hline $100 \%$ & $0 \%$ & $0 \%$ & $0 \%$ & $0 \%$ & $100 \%$ & Percentage \\
\hline
\end{tabular}

All sample members strongly agreed $100 \%$ to a paragraph: My country's history, heritage, and customs are a source of pride.

Table No. (10)

Table No. (10) shows the responses of the sample members to a paragraph: I am fully repaired to sacrifice the soul for the sake of my country.

\begin{tabular}{|c|c|c|c|c|c|c|}
\hline Total & $\begin{array}{c}\text { Strongly } \\
\text { disagree }\end{array}$ & Disagree & Neutral & Agree & $\begin{array}{c}\text { Strongly } \\
\text { agree }\end{array}$ & $\begin{array}{c}\text { Degree of } \\
\text { approval }\end{array}$ \\
\hline 200 & 0 & 0 & 0 & 0 & 200 & Numbers \\
\hline $100 \%$ & $0 \%$ & $0 \%$ & $0 \%$ & $0 \%$ & $100 \%$ & Percentage \\
\hline
\end{tabular}

All members of the sample strongly agreed, and 100\% strongly agreed with a paragraph: I am fully prepared to sacrifice my soul for the sake of my country.

Table No. (11)

Table No. (11) shows the responses of the sample members to a paragraph: I appreciate my job and respect work times.

\begin{tabular}{|c|c|c|c|c|c|c|}
\hline Total & $\begin{array}{c}\text { Strongly } \\
\text { disagree }\end{array}$ & Disagree & Neutral & Agree & $\begin{array}{c}\text { Strongly } \\
\text { agree }\end{array}$ & $\begin{array}{c}\text { Degree of } \\
\text { approval }\end{array}$ \\
\hline 200 & 0 & 0 & 11 & 81 & 108 & Numbers \\
\hline $100 \%$ & $0 \%$ & $0 \%$ & $5.5 \%$ & $40.5 \%$ & $54 \%$ & Percentage \\
\hline
\end{tabular}

It is clear from Table No. (11) that $54 \%$ of respondents strongly agreed with the above paragraph, followed by a degree of approval, were agree with a rate of $40.5 \%$, while those who maintained neutrality from the sample members were 5.5.

Table No. (12)

Table No. (12) shows the responses of the sample members to a paragraph: Participate in every activity that preserves the unity of the Emirate. 


\begin{tabular}{|c|c|c|c|c|c|c|}
\hline Total & $\begin{array}{c}\text { Strongly } \\
\text { disagree }\end{array}$ & Disagree & Neutral & Agree & $\begin{array}{c}\text { Strongly } \\
\text { agree }\end{array}$ & $\begin{array}{c}\text { Degree of } \\
\text { approval }\end{array}$ \\
\hline 300 & 0 & 0 & 0 & 0 & 200 & Numbers \\
\hline $100 \%$ & $0 \%$ & $0 \%$ & $0 \%$ & $0 \%$ & $100 \%$ & Percentage \\
\hline
\end{tabular}

All members of the sample strongly agreed, and 100\% strongly agree to a paragraph: I participate in every activity that preserves the unity of the Emirates.

Table No. (13)

\begin{tabular}{|c|c|c|c|c|c|c|}
\hline Total & $\begin{array}{c}\text { Strongly } \\
\text { disagree }\end{array}$ & Disagree & Neutral & Agree & $\begin{array}{c}\text { Strongly } \\
\text { agree }\end{array}$ & $\begin{array}{c}\text { Degree of } \\
\text { approval }\end{array}$ \\
\hline 200 & 0 & 0 & 7 & 116 & 77 & Numbers \\
\hline $100 \%$ & $0 \%$ & $0 \%$ & $3.5 \%$ & $58 \%$ & $38.5 \%$ & Percentage \\
\hline
\end{tabular}

(116) members of the sample agreed on a clause: It was adhered to the regulations and laws out of self-censorship, and their rate of agreeing reached $58 \%$, that is, more than half, followed by a strongly agree category, and the percentage was $38.5 \%$, while the neutral group received a percentage of $3.5 \%$.

Table No. (14)

Table No. (14) shows the responses of the sample members to a paragraph: My commitment to the UAE is among my top concern.

\begin{tabular}{|c|c|c|c|c|c|c|}
\hline Total & $\begin{array}{c}\text { Strongly } \\
\text { disagree }\end{array}$ & Disagree & Neutral & Agree & $\begin{array}{c}\text { Strongly } \\
\text { agree }\end{array}$ & $\begin{array}{c}\text { Degree of } \\
\text { approval }\end{array}$ \\
\hline 200 & 0 & 0 & 0 & 0 & 200 & Numbers \\
\hline $100 \%$ & $0 \%$ & $0 \%$ & $0 \%$ & $0 \%$ & $100 \%$ & Percentage \\
\hline
\end{tabular}

The approval came strongly from all members of the sample and $100 \%$ of the paragraph: My commitment to the UAE is at the forefront of my interests.

Table No. (15)

Table No. (15) shows the responses of the sample members to a paragraph: He actively contributed to everything that would raise my country.

\begin{tabular}{|c|c|c|c|c|c|c|}
\hline Total & $\begin{array}{c}\text { Strongly } \\
\text { disagree }\end{array}$ & Disagree & Neutral & Agree & $\begin{array}{c}\text { Strongly } \\
\text { agree }\end{array}$ & $\begin{array}{c}\text { Degree of } \\
\text { approval }\end{array}$ \\
\hline 200 & 0 & 0 & 0 & 0 & 200 & Numbers \\
\hline $100 \%$ & $0 \%$ & $0 \%$ & $0 \%$ & $0 \%$ & $100 \%$ & Percentage \\
\hline
\end{tabular}

All members of the sample strongly agreed, and 100\% agreed on a paragraph: My commitment to the UAE is one of my top concerns.

The second axis: the elements of exercising the values of citizenship among Emirati youth.

Table No. (16)

Table No. (16) shows the respondents 'answers to a paragraph: Justice and equality are achieved in my country. 


\begin{tabular}{|c|c|c|c|c|c|c|}
\hline Total & $\begin{array}{c}\text { Strongly } \\
\text { disagree }\end{array}$ & Disagree & Neutral & Agree & $\begin{array}{c}\text { Strongly } \\
\text { agree }\end{array}$ & $\begin{array}{c}\text { Degree of } \\
\text { approval }\end{array}$ \\
\hline 200 & 0 & 0 & 10 & 20 & 170 & Numbers \\
\hline $100 \%$ & $0 \%$ & $0 \%$ & $0 \%$ & $10 \%$ & $90 \%$ & Percentage \\
\hline
\end{tabular}

Justice and equality is an investigator in my country: the respondents' attitudes came as follows: $90 \%$ strongly agree, followed by $10 \%$ agree, while the rest of the trends scored $0 \%$.

Table No. (17)

Table No. (17) shows the respondents' answers to a paragraph: I have the freedom to own property according to the law.

\begin{tabular}{|c|c|c|c|c|c|c|}
\hline Total & $\begin{array}{c}\text { Strongly } \\
\text { disagree }\end{array}$ & Disagree & Neutral & Agree & $\begin{array}{c}\text { Strongly } \\
\text { agree }\end{array}$ & $\begin{array}{c}\text { Degree of } \\
\text { approval }\end{array}$ \\
\hline 200 & 0 & 0 & 0 & 0 & 200 & Numbers \\
\hline $100 \%$ & $0 \%$ & $0 \%$ & $0 \%$ & $0 \%$ & $100 \%$ & Percentage \\
\hline
\end{tabular}

To answer this paragraph, all the answers of the sample respondents came strongly, that is, $100 \%$.

Table No. (18)

Table No. (18) shows the responses of the sample members to a paragraph: Education is available to all in my country.

\begin{tabular}{|c|c|c|c|c|c|c|}
\hline Total & $\begin{array}{c}\text { Strongly } \\
\text { disagree }\end{array}$ & Disagree & Neutral & Agree & $\begin{array}{c}\text { Strongly } \\
\text { agree }\end{array}$ & $\begin{array}{c}\text { Degree of } \\
\text { approval }\end{array}$ \\
\hline 200 & 0 & 0 & 0 & 0 & 200 & Numbers \\
\hline $100 \%$ & $0 \%$ & $0 \%$ & $0 \%$ & $0 \%$ & $100 \%$ & Percentage \\
\hline
\end{tabular}

To answer this paragraph, all the answers of the sample respondents came strongly, that is, $100 \%$.

Table No. (19)

Table No. (19) shows the respondents' answers to a paragraph: I enjoy the freedom of expression and opinion.

\begin{tabular}{|c|c|c|c|c|c|c|}
\hline Total & $\begin{array}{c}\text { Strongly } \\
\text { disagree }\end{array}$ & Disagree & Neutral & Agree & $\begin{array}{c}\text { Strongly } \\
\text { agree }\end{array}$ & $\begin{array}{c}\text { Degree of } \\
\text { approval }\end{array}$ \\
\hline 200 & 0 & 0 & 0 & 0 & 200 & Numbers \\
\hline 1005 & $0 \%$ & $0 \%$ & $0 \%$ & $0 \%$ & $100 \%$ & Percentage \\
\hline
\end{tabular}

Strong approval of this paragraph came from all members of the sample is $100 \%$.

Table No. (20)

Table No. (20) shows respondents' responses to a paragraph: The right to work is available to everyone in my country. 


\begin{tabular}{|c|c|c|c|c|c|c|}
\hline Total & $\begin{array}{c}\text { Strongly } \\
\text { disagree }\end{array}$ & Disagree & Neutral & Agree & $\begin{array}{c}\text { Strongly } \\
\text { agree }\end{array}$ & $\begin{array}{c}\text { Degree of } \\
\text { approval }\end{array}$ \\
\hline 200 & 0 & 0 & 0 & 0 & 200 & Numbers \\
\hline $100 \%$ & $0 \%$ & $0 \%$ & $0 \%$ & $0 \%$ & $100 \%$ & Percentage \\
\hline
\end{tabular}

Strong approval of this phrase came from all members of the sample is $100 \%$.

Table No. (21)

Table No. (21) shows respondents' responses to a paragraph: The right to services provided by the state is guaranteed to all.

\begin{tabular}{|c|c|c|c|c|c|c|}
\hline Total & $\begin{array}{c}\text { Strongly } \\
\text { disagree }\end{array}$ & Disagree & Neutral & Agree & $\begin{array}{c}\text { Strongly } \\
\text { agree }\end{array}$ & $\begin{array}{c}\text { Degree of } \\
\text { approval }\end{array}$ \\
\hline 200 & 0 & 0 & 0 & 0 & 200 & Numbers \\
\hline $100 \%$ & $0 \%$ & $0 \%$ & $0 \%$ & $0 \%$ & $100 \%$ & Percentage \\
\hline
\end{tabular}

Strong agree approval of this paragraph came from all members of the sample is $100 \%$.

Table No. (22)

Table No. (22) shows the responses of the sample members to a paragraph: The right to political participation in my country is available to all.

\begin{tabular}{|c|c|c|c|c|c|c|}
\hline Total & $\begin{array}{c}\text { Strongly } \\
\text { disagree }\end{array}$ & Disagree & Neutral & Agree & $\begin{array}{c}\text { Strongly } \\
\text { agree }\end{array}$ & $\begin{array}{c}\text { Degree of } \\
\text { approval }\end{array}$ \\
\hline 200 & 0 & 0 & 0 & 24 & 176 & Numbers \\
\hline $100 \%$ & $0 \%$ & $0 \%$ & $0 \%$ & $12 \%$ & $88 \%$ & Percentage \\
\hline
\end{tabular}

It is clear from Table (23) that $88 \%$ of respondents strongly agree with the right to political participation in my country, available to all, while $12 \%$ of respondents agreed with success, meaning that all respondents answered with consent.

Table No. (23)

Table No. (23) shows the respondents' answers to a paragraph: I feel safe in my country and live in peace.

\begin{tabular}{|c|c|c|c|c|c|c|}
\hline Total & $\begin{array}{c}\text { Strongly } \\
\text { disagree }\end{array}$ & Disagree & Neutral & Agree & $\begin{array}{c}\text { Strongly } \\
\text { agree }\end{array}$ & $\begin{array}{c}\text { Degree of } \\
\text { approval }\end{array}$ \\
\hline 200 & 0 & 0 & 0 & 0 & 200 & Numbers \\
\hline $100 \%$ & $0 \%$ & $0 \%$ & $0 \%$ & $0 \%$ & $100 \%$ & Percentage \\
\hline
\end{tabular}

Strong approval of this phrase came from all members of the sample $100 \%$.

Table No. (24)

Table No. (24) shows the responses of the sample members to a paragraph: The right is to be informed about everything related to the country is available to the citizen.

\begin{tabular}{|c|c|c|c|c|c|c|}
\hline Total & $\begin{array}{c}\text { Strongly } \\
\text { disagree }\end{array}$ & Disagree & Neutral & Agree & $\begin{array}{c}\text { Strongly } \\
\text { agree }\end{array}$ & $\begin{array}{c}\text { Degree of } \\
\text { approval }\end{array}$ \\
\hline 200 & 0 & 0 & 0 & 0 & 200 & Numbers \\
\hline $100 \%$ & $0 \%$ & $0 \%$ & $0 \%$ & $0 \%$ & $100 \%$ & Percentage \\
\hline
\end{tabular}


Strong approval of this phrase came from all members of the sample is $100 \%$.

Table No. (25)

Table No. (25) shows the responses of the sample members to a paragraph: the circumstances of the age reduced the sense of belonging to the country.

\begin{tabular}{|c|c|c|c|c|c|c|}
\hline Total & $\begin{array}{c}\text { Strongly } \\
\text { disagree }\end{array}$ & Disagree & Neutral & Agree & $\begin{array}{c}\text { Strongly } \\
\text { agree }\end{array}$ & $\begin{array}{c}\text { Degree of } \\
\text { approval }\end{array}$ \\
\hline 200 & 35 & 144 & 0 & 21 & 0 & Numbers \\
\hline $100 \%$ & $17.5 \%$ & $72 \%$ & $0 \%$ & $10.5 \%$ & $0 \%$ & Percentage \\
\hline
\end{tabular}

The above table shows that the majority of respondents did not agree that the circumstances of the age reduced the sense of belonging to the homeland, and the results came as follows: $72 \%$ of them answered disagree $17.5 \%$ who were not very successful were strongly disagree, while those who answered with approval were agreed $10.5 \%$

Table No. (26)

Table No. (26) shows the responses of the sample members to a paragraph: Most of the strange political ideas are destructive and not suitable for our society.

\begin{tabular}{|c|c|c|c|c|c|c|}
\hline Total & $\begin{array}{c}\text { Strongly } \\
\text { disagree }\end{array}$ & Disagree & Neutral & Agree & $\begin{array}{c}\text { Strongly } \\
\text { agree }\end{array}$ & $\begin{array}{c}\text { Degree of } \\
\text { approval }\end{array}$ \\
\hline 200 & 0 & 0 & 24 & 66 & 110 & Numbers \\
\hline $100 \%$ & $0 \%$ & $0 \%$ & $12 \%$ & $33 \%$ & $55 \%$ & Percentage \\
\hline
\end{tabular}

The respondents' responses to the above paragraph came as follows: $55 \%$ of them strongly agree, $33 \%$ of the respondents answered with approval, and those who stood in the fence were $12 \%$, and the rest of the phrases got $0 \%$.

Table No. (27)

Table No. (27) shows the responses of the sample members to a paragraph: Globalization has a role in weakening the values of citizenship among youth.

\begin{tabular}{|c|c|c|c|c|c|c|}
\hline Total & $\begin{array}{c}\text { Strongly } \\
\text { disagree }\end{array}$ & Disagree & Neutral & Agree & $\begin{array}{c}\text { Strongly } \\
\text { agree }\end{array}$ & $\begin{array}{c}\text { Degree of } \\
\text { approval }\end{array}$ \\
\hline 200 & 14 & 97 & 44 & 35 & 10 & Numbers \\
\hline $100 \%$ & $7 \%$ & $48.5 \%$ & $22 \%$ & $17.5 \%$ & $5 \%$ & Percentage \\
\hline
\end{tabular}

It is clear from Table (27) that $48.5 \%$ of respondents answered with strongly disagree, without agreeing to a paragraph on globalization, a role in weakening the values of citizenship among young people, followed by a neutral statement, and it was at a rate of $22 \%$. On the other hand, the percentage of those who agreed with the phrase was $17.5 \%$. Finally, the percentage of those who agreed strongly is $5 \%$ of the total sample population.

Table No. (28)

Table No. (28) shows the responses of the sample members to a paragraph: The expatriate workforce has a great effect in weakening the concept of citizenship among young people.

\begin{tabular}{|c|c|c|c|c|c|c|}
\hline Total & $\begin{array}{c}\text { Strongly } \\
\text { disagree }\end{array}$ & Disagree & Neutral & Agree & $\begin{array}{c}\text { Strongly } \\
\text { agree }\end{array}$ & $\begin{array}{c}\text { Degree of } \\
\text { approval }\end{array}$ \\
\hline 200 & 21 & 144 & 0 & 35 & 0 & Numbers \\
\hline $100 \%$ & $10.5 \%$ & $72 \%$ & $0 \%$ & $17.5 \%$ & $0 \%$ & Percentage \\
\hline
\end{tabular}


To reveal the effect of expatriate workers on weakening the concept of citizenship among young people, the answers of the sample members came as follows: Those who answered without approval amounted to $72 \%$, those who agreed were $17.5 \%$, and those who strongly disagreed came to $10.5 \%$.

Table No. (29)

Table No. (29) shows respondents' responses to a paragraph: The new media weakens the concept of citizenship among young people.

\begin{tabular}{|c|c|c|c|c|c|c|}
\hline Total & $\begin{array}{c}\text { Strongly } \\
\text { disagree }\end{array}$ & Disagree & Neutral & Agree & $\begin{array}{c}\text { Strongly } \\
\text { agree }\end{array}$ & $\begin{array}{c}\text { Degree of } \\
\text { approval }\end{array}$ \\
\hline 200 & 32 & 126 & 7 & 35 & 0 & Numbers \\
\hline $100 \%$ & $16 \%$ & $63 \%$ & $3.5 \%$ & $17.5 \%$ & $0 \%$ & Percentage \\
\hline
\end{tabular}

It is clear from Table (29) that more than half of the number of individuals, at a rate of $63 \%$, answered without agreeing to the role of the new media in weakening the concept of citizenship among young people. On the other hand, the percentage of those who agreed, $17.5 \%$, came strongly disagreeing $16 \%$, followed by a neutral group and was $3.5 \%$.

Table No. (30)

Table No. (30) shows the responses of the sample members to a paragraph: Increasing belonging to the country means fanaticism.

\begin{tabular}{|c|c|c|c|c|c|c|}
\hline Total & $\begin{array}{c}\text { Strongly } \\
\text { disagree }\end{array}$ & Disagree & Neutral & Agree & $\begin{array}{c}\text { Strongly } \\
\text { agree }\end{array}$ & $\begin{array}{c}\text { Degree of } \\
\text { approval }\end{array}$ \\
\hline 200 & 200 & 0 & 0 & 0 & 0 & Numbers \\
\hline $100 \%$ & $100 \%$ & $0 \%$ & $\% 0$ & $0 \%$ & $0 \%$ & Percentage \\
\hline
\end{tabular}

All members of the sample answered the paragraph of increasing affiliation to the homeland, meaning intolerance without approval, and at a rate of $100 \%$.

Table No. (31)

Table No. (31) shows the responses of the sample members to a paragraph: I do not care to adhere to social customs and traditions.

\begin{tabular}{|c|c|c|c|c|c|c|}
\hline Total & $\begin{array}{c}\text { Strongly } \\
\text { disagree }\end{array}$ & Disagree & Neutral & Agree & $\begin{array}{c}\text { Strongly } \\
\text { agree }\end{array}$ & $\begin{array}{c}\text { Degree of } \\
\text { approval }\end{array}$ \\
\hline 300 & 179 & 21 & 0 & 0 & 0 & Numbers \\
\hline $100 \%$ & $89.5 \%$ & $10.5 \%$ & $0 \%$ & $0 \%$ & $0 \%$ & Percentage \\
\hline
\end{tabular}

It is clear from Table (31) that all members of the sample did not agree to a paragraph. I do not care to adhere to social customs and traditions, as the proportion of those who did not strongly agree strongly reached $89.5 \%$, and the percentage of those who answered disapproved came $10.5 \%$.

Table No. (32)

Table No. (32) shows the responses of the sample members to a paragraph: The abnormal intellectual currents work to destroy the values of citizenship. 


\begin{tabular}{|c|c|c|c|c|c|c|}
\hline Total & $\begin{array}{c}\text { Strongly } \\
\text { disagree }\end{array}$ & Disagree & Neutral & Agree & $\begin{array}{c}\text { Strongly } \\
\text { agree }\end{array}$ & $\begin{array}{c}\text { Degree of } \\
\text { approval }\end{array}$ \\
\hline 200 & 77 & 83 & 20 & 17 & 3 & Numbers \\
\hline $100 \%$ & $38.5 \%$ & $41.5 \%$ & $10 \%$ & $8.5 \%$ & $1.5 \%$ & Percentage \\
\hline
\end{tabular}

Table No. (32) shows that $41.5 \%$ of the sample respondents do not agree with the role of intellectual currents in demolishing citizenship values, while the percentage of a category came strongly disagree $38.5 \%, 10 \%$ Neutral, and $8.5 \%$ agree, and finally, strongly agreed, it was only $1.5 \%$ strongly agree.

Table No. (33)

Table No. (33) shows the responses of the sample members to a paragraph: Multinationalism and ideological affiliations threaten the ties of national unity.

\begin{tabular}{|c|c|c|c|c|c|c|}
\hline Total & $\begin{array}{c}\text { Strongly } \\
\text { disagree }\end{array}$ & Disagree & Neutral & Agree & $\begin{array}{c}\text { Strongly } \\
\text { agree }\end{array}$ & $\begin{array}{c}\text { Degree of } \\
\text { approval }\end{array}$ \\
\hline 200 & 52 & 98 & 32 & 12 & 6 & Numbers \\
\hline $100 \%$ & $26 \%$ & $49 \%$ & $16 \%$ & $6 \%$ & $3 \%$ & Percentage \\
\hline
\end{tabular}

While the multiplicity of nationalities and ideological affiliations threatens national unity ties, the responses of the sample members came as follows: $49 \%$ disagree, disagree strongly $26 \%$, neutral, $16 \%$, agree $6 \%$, strongly agree $3 \%$.

Table No. (34)

Table No. (34) shows the responses of the sample members to a paragraph: Media openness has a negative effect on citizen awareness.

\begin{tabular}{|c|c|c|c|c|c|c|}
\hline Total & $\begin{array}{c}\text { Strongly } \\
\text { disagree }\end{array}$ & Disagree & Neutral & Agree & $\begin{array}{c}\text { Strongly } \\
\text { agree }\end{array}$ & $\begin{array}{c}\text { Degree of } \\
\text { approval }\end{array}$ \\
\hline 200 & 73 & 114 & 9 & 4 & 0 & Numbers \\
\hline $100 \%$ & $36.5 \%$ & $57 \%$ & $4.5 \%$ & $2 \%$ & $0 \%$ & Percentage \\
\hline
\end{tabular}

To reveal the extent of the impact of media openness and the negative impact on the citizen's awareness, $57 \%$ of respondents said that they disagreed. The percentage of those who answered strongly disagree came with $36.5 \%$; those who stood in neutral are $4.5 \%$ and came from those who answered with approval from the respondents $2 \%$.

\section{Presenting and Discussing the Results:}

1 / The study results showed that more than $90 \%$ of respondents are fully aware of the concept of citizenship and feel proud that they are citizens of the United Arab Emirates.

2 / The study results showed that all members of the sample owe loyalty to the country, cherish its heritage and adhere to its customs.

3 / The study results showed that all members of the sample contribute to supporting the values of citizenship through community participation in activities that work to preserve the unity of the Emirates.

4 / The study results showed that the overwhelming majority of the sample, with a percentage of more than $90 \%$, enjoy the rights to ownership, expression, work, and political participation and feel security inside the country.

5 / The study results showed that there are no negative effects of media openness and new 
media on citizen awareness.

6 / It was found through the study results that there are no negative effects of the presence of expatriate workers and multinationals within the country that weaken the concept of citizenship among the sample members.

\section{Recommendations and Proposals:}

According to the research results, the researcher recommends the following:

1 / The necessity of giving the concept of citizenship the utmost importance in the media and school curricula.

2 / The necessity to support and enhance the concept of citizenship among youth by launching community-led youth initiatives.

3 / Immunizing youth against the negative effects of media openness and the new media by focusing on developing the values of citizenship.

4 / Paying attention to the historical, religious, and civilizational symbols and promoting them by means of tourism to enhance the concept of citizenship among the people of one country.

5 / Motivating youth to loyal to the country, cherish its heritage, and adhere to its customs.

\section{Future research:}

The researcher recommends:

1-A study on the importance of including the concept of citizenship in school curricula.

2-A study on establishing the values of national identity among young people.

\section{References}

AlIPORT, G. W. (1954). The Nature of prejudice. Cambridge, Addison, Wesley, p.45.

Al-Amer, O. b. (2005). The effect of cultural openness on the concept of citizenship among Saudi youth, a study conducted for the thirteenth annual meeting of educational action leaders, Al-Baha, Saudi Arabia.

Al-Azmi, M. S.-R. (2011). The Role of Teachers in Developing National Values for High School Students in the State of Kuwait. The Educational Journal of Kuwait University, Twenty-fifth Volume, Ninety-ninth Issue, Part Two, June.

Al-Azzawi, P. D. (n.d.). The concept of citizenship among Iraqi youth, Childhood Motherhood Research Center, Diyala University.

Al-Gohary, A.-H. a. (1996). Studies in Social Development. An Islamic entry: Renaissance Renaissance Library, p. 169.

Al-Habib, F. I. (2015). Citizenship Education, Contemporary Trends in Citizenship Education. Riyadh: 1st Floor, Obeikan Library.

Al-Habib, F. I. (2015). Citizenship Education. Contemporary Trends in Citizenship Education, 1st Floor, Riyadh, Obeikan Library.

Al-Kabbaj, M. M. (2006). Orbits of contemporary citizenship towards a new concept of citizenship in the era of blocs.

Al-Kafi, I. A.-F. (2005). Encyclopedia of Islamic Values and Ethics. Alexandria: Alexandria Book Center, p. 18.

Al-Nabhani, S. b. (2007). Citizenship and Contemporary Challenges in Omani Society, quoted from the Internet on 9/5/2018 - 9:10.

Al-Qahtani, A. S. (2010). Values of citizenship among youth and their contribution to enhancing 
preventive security. Unpublished doctoral dissertation, Naif Arab University for Security Sciences.

Al-Sabeeh, A. N. (2005). Citizenship as envisioned by high school students in the Kingdom of Saudi Arabia and its relationship to some social institutions. Paper presented to the thirteenth annual meeting of educational action leaders. Al-Baha, KSA.

Amara, S. F. (2010). The role of the university professor in developing the values of citizenship to face the challenges of cultural identity, Alexandria University as a model. Future of Arab Education magazine, No. 64, June, the Arab Center for Education and development.

Bougardous. (1931). Fundamental of Psychology. 2nd Edition and Grofts, 1931, p444.

El-Sayed, A.-F. G. (2010). The university's role in educating students about the principles of citizenship is an input necessitated by contemporary global challenges-Journal of Educational and Psychological Studies, Faculty of Education, Zagazig University No.66 Part two January.

Ghaith, M. A. (1995). Dictionary of Sociology. Alexandria.: University Knowledge House.

Hijazi, M. (2006). The Lost Man: An Analytic Psychosocial Study -. Casablanca, Morocco: The Arab Cultural Center -, 2nd edition.

Ibn Arab, A. K. (2009). Citizenship between dream and reality. Citing the Internet on 04/24/2018.

Ibn Manzur R, A. A.-F.-D. (1968). Lisan Al-Arab,. Beirut - Lebanon,: 3 vol. 5, Dar Sad - .

Idris, J. S. (2005). Citizenship and Identity. Article published in Al-Bayan Magazine No. 211.18.

Jaafar Sheikh Idris. (2005). Citizenship and Identity. Article published in Al-Bayan Magazine No. 211.18.

Library, A.-S. I. (2014). The Intermediate Dictionary. 470.

Lung, C. (2004). Civic Education Reform in Hong Kong Primary Schools. Journal of Basic Education. Vol. 13 No. 1 , pp. $25-34$.

R, I. M. (1968). Abi Al-Fadl Jamal Al-Din Lisan Al-Arab. Lebanon: 3 vol. 5, Dar Sad - Beirut.

Sami Mahdi Al-Azzawi. (n.d.). The concept of citizenship among Iraqi youth. Childhood Motherhood Research Center, Diyala University.

Shamani, S. L., \& Saad, A. Y. (2012). University youth, affiliation issues, opportunities and challenges, students of Taibah University as a model. Journal of Educational Sciences, Volume 20, No. 1.

Sim, J. (2005). Citizenship Education and Social Studies in Singapore: A National Agenda. International Journal of Citizenship and Teacher Education, Vol. 1, No. 1, July.

SRC. (2018). Studies and Research in Values. The Kingdom of Morocco.

Warwick, P. (2007). revealing the need for citizenship education within primary schools. Education Journal 3-13, Volume 35, Issue 3, August, pp. 261 - 272.

Woyach, R. B. (1992). Leadership in civic education. ERIC Digest, Publication. 